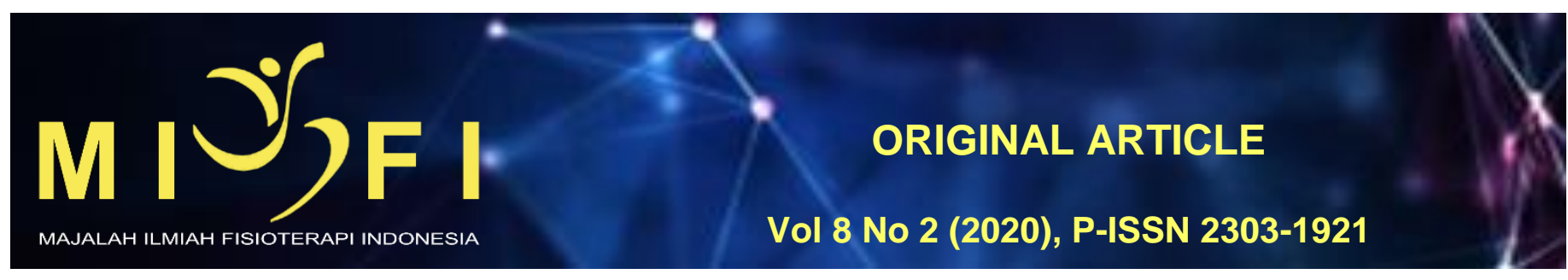

\title{
HUBUNGAN GENERALIZED JOINT HYPERMOBILITY (GJH) DENGAN KESEIMBANGAN STATIS PADA PENARI DI KOTA DENPASAR
}

\author{
Elfiera Kang ${ }^{1}$, Ni Luh Nopi Andayani ${ }^{2}$, Nila Wahyuni ${ }^{3}$, Luh Putu Ratna Sundari ${ }^{4}$ \\ ${ }^{1}$ Program Studi Fisioterapi dan Profesi Fisioterapi Fakultas Kedokteran Universitas Udayana, Denpasar \\ ${ }^{2}$ Departemen Fisioterapi Fakultas Kedokteran Universitas Udayana, Denpasar \\ 3,4Departemen IImu Faal Fakultas Kedokteran Universitas Udayana, Denpasar \\ elfierakang@gmail.com
}

\begin{abstract}
ABSTRAK
Keseimbangan adalah komponen yang penting dalam kehidupan manusia. Keseimbangan terdiri dari keseimbangan statis dan dinamis. Keseimbangan statis adalah dasar terbentuknya keseimbangan dinamis. Jika keseimbangan statis terganggu, keseimbangan dinamis pun akan mengalami gangguan. Menari adalah aktivitas yang membutuhkan fungsi keseimbangan yang tinggi. Gerakan tarian yang repetitif dan melebihi lingkup gerak sendi dapat menyebabkan kondisi generalized joint hypermobility (GJH) pada penari. Tujuan Penelitian ini adalah untuk dapat menganalisis adanya hubungan antara generalized joint hypermobility $(\mathrm{GJH})$ dengan keseimbangan statis pada penari di Kota Denpasar. Metode pada penelitian ini merupakan penelitian analitik cross sectional yang dilakukan pada bulan April-Mei 2019. Jumlah sampel pada penelitian ini adalah 48 perempuan usia 16-25 tahun. Variabel independen yang diukur ialah generalized joint hypermobility (GJH) dengan menggunakan beighton score. Pengukuran variabel dependen, yaitu keseimbangan statis dilakukan dengan standing stork test. Uji korelasi dengan uji Spearman's Rho menunjukan hasil $p=0,000(p<0,05)$. Hasil tersebut menunjukkan hubungan yang signifikan antara generalized joint hypermobility $(\mathrm{GJH})$ dengan keseimbangan statis pada penari usia 16-25 tahun di Kota Denpasar.
\end{abstract}

Kata kunci: Generalized Joint Hypermobility, Keseimbangan Statis, Penari, Beighton Score, Standing Stork Test.

\section{THE CORRELATIONS BETWEEN GENERALIZED JOINT HYPERMOBILITY (GJH) AND STATIC BALANCE AMONG DANCERS IN DENPASAR}

\section{ABSTRACT}

Balance is an important component in human life. Human balance consists of static and dynamic balance. Static balance is the basis of dynamic balance formation. If static balance is interrupted, the dynamic balance will also be impaired. Dancing is an activity that requires a high balance function. Repetitive dance movements that exceed the scope of motion can cause generalized joint hypermobility $(\mathrm{GJH})$ conditions in dancers. The purpose of this research is to analyze the correlation between the generalized joint hypermobility $(\mathrm{GJH})$ and the static balance of dancers in Denpasar. The method used is cross sectional analytic conducted in April-May 2019. The number of samples on this study was 48 females aged 16-25 years. The independent variable measured is a generalized joint hypermobility (GJH) using the beighton score. Measurement of dependent variable, which is static balance is done with standing stork test. After obtaining the research result, data normality test conducted with Kolmogorov Smirnov Test. Subsequently, a correlation test was conducted with Spearman's Rho test which showed the correlation between the two groups $(p=$ 0.000). Based on the results of the study, it can be concluded that there is a correlation between the generalized joint hypermobility $(\mathrm{GJH})$ with a static balance in the dancer age 16-25 years in Denpasar.

Keywords: Generalized Joint Hypermobility, Keseimbangan Statis, Penari, Beighton Score, Standing Stork Test.

\section{PENDAHULUAN}

Keseimbangan merupakan komponen yang penting dalam kehidupan manusia. Tubuh manusia akan selalu berusaha mempertahankan posisinya agar tetap seimbang. Aktivitas ringan maupun berat membutuhkan fungsi keseimbangan tubuh yang baik. Keseimbangan adalah kemampuan untuk mempertahankan sistem neuromuskular dalam kondisi statis, atau mengontrol sistem neuromuskular tersebut dalam suatu posisi atau sikap yang efisien saat tubuh bergerak ${ }^{1}$.

Terdapat dua jenis keseimbangan yaitu keseimbangan statis (static balance) dan keseimbangan dinamis (dynamic balance). Dalam keseimbangan statis, ruang gerak tubuh sangat minimal seperti berdiri di atas dasar yang sempit atau balok keseimbangan sedangkan keseimbangan dinamis, yaitu kemampuan tubuh untuk bergerak dari satu titik ke titik yang lain dengan mempertahankan keseimbangan (equilibrium). Keseimbangan dipengaruhi oleh beberapa faktor, baik internal maupun eksternal. Faktor-faktor tersebut antara lain genetik, usia, fungsi vestibular, proprioseptif, status emosional, based of support (BOS), kekuatan otot, fleksibilitas, dan tingkat aktivitas fisik ${ }^{2}$. Menari merupakan aktivitas yang membutuhkan kemampuan keseimbangan yang baik. Kesiapan tubuh secara fisik sangat penting bagi seorang penari untuk melakukan aktivitas gerak tari ${ }^{3}$. Kemampuan tubuh yang baik adalah hasil dari koordinasi kekuatan, kecepatan, daya tahan, kelincahan, kelenturan, dan ketepatan. Dengan terpenuhinya hal tersebut maka akan terbentuk keseimbangan gerak pada tubuh penari. Fungsi keseimbangan yang terganggu akan berdampak pada 
meningkatnya risiko terjatuh dan menyebabkan cedera pada penari. Beberapa peneliti menduga adanya beberapa faktor intrinsik yang mempengaruhi cedera pada penari, seperti ketidakseimbangan kekuatan dan fleksibilitas otot, lingkup gerak sendi (joint range of motion) yang berlebihan atau buruknya postur tubuh (postural alignment) ${ }^{4}$

Penari adalah perpaduan unik antara artis dan atlet yang sangat rentan terhadap cedera muskuloskeletal dan nyeri. Dalam tarian terdapat tuntutan interaksi antara kemampuan fisik dan estetika ${ }^{5}$. Unsur estetika menuntut penari untuk memiliki mobilitas sendi dan fleksibilitas yang tinggi. Salah satu jenis tarian adalah tari modern. Tari modern adalah tarian yang sangat bebas dari segi gerakan dan kreativitas. Tari modern tidak memiliki pakem tertentu seperti tari tradisional dan tari balet. Gerakan yang sangat bebas pada tari modern menyebabkan tingginya risiko cedera pada penari modern. Gerakan tarian modern memanfaatkan seluruh anggota tubuh dalam mencapai unsur estetika yaitu dengan lingkup gerak sendi yang maksimal6.

Generalized joint hypermobility (GJH) adalah suatu keadaan dimana terdapat peningkatan mobilitas dari sendi kecil dan besar dalam tubuh7. Kondisi GJH merupakan salah satu faktor yang menunjang penari dalam mencapai unsur estetika. Prevalensi GJH pada penari bervariasi antara 11\% - 97\% tergantung usia, jenis kelamin, dan ras. Prevalensi GJH lebih tinggi pada perempuan usia 14-20 tahun dan lebih tinggi pada ras Asia dan Afrika ${ }^{8}$. Jika dibandingkan pada populasi umum, penari dengan GJH memiliki presentase hingga 35\% ${ }^{9}$. Penelitian yang dilakukan di Australia pada 85 penari menunjukkan bahwa terdapat $76 \%$ penari dengan GJH dan sebagian besar adalah penari perempuan ${ }^{10}$.

Penari dengan sendi yang fleksibel menguntungkan dalam unsur estetika, namun GJH dapat menghambat performa penari. GJH adalah kondisi yang tidak memiliki gejala (asymptomatic). Perhatian penari dan pelatih tari akan kondisi GJH sangatlah kurang. GJH asimptomatik yang berkelanjutan dan tanpa penanganan yang serius dapat berujung pada kondisi GJH simptomatik. GJH simptomatik dapat menghambat performa penari dan menyebabkan pensiun dini akibat keluhan yang ditumbulkannya. GJH dapat menyebabkan terjadinya osteoarthritis (OA) dini pada penari11.

GJH pada penari menyebabkan menurunnya tingkat kebugaran fisik, meningkatnya tingkat kelelahan otot dan meningkatnya tingkat stres psikologis jika dibandingkan dengan penari yang tidak memiliki hipermobilitas sendi ${ }^{9}$. Kelemahan otot dan atropi otot sering ditemukan pada GJH non-simptomatis (pada penari) maupun GJH simptomatis (pada pasien Ehlers Danlos Syndrome-Hypermobile)12. Kondisi sendi yang longgar pada GJH menyebabkan terganggunya fungsi proprioseptif sendi.

Proprioseptif menyediakan informasi kepada otak terkait posisi dan sensasi gerak sendi melalui mekanoreseptor yang terdapat pada kapsul sendi, otot, dan tendon ${ }^{13}$. Fungsi proprioseptif yang buruk pada GJH menyebabkan terganggunya kontrol postural dan keseimbangan statis ${ }^{14}$. Keseimbangan statis dapat mempengaruhi keseimbangan dinamis. Hingga saat ini masih sedikit studi yang meneliti hubungan antara GJH dengan fungsi keseimbangan statis pada penari.

Dalam beberapa tahun teraktir, tari modern berkembang secara pesat di Bali khususnya di Kota Denpasar. Jumlah penari pun semakin meningkat dan membutuhkan perhatian khusus terkait kondisi fisik dan gerak. Penelitian ilmiah pada penari masih sangat sedikit jumlahnya di Indonesia. Oleh karena itu penulis merasa penting untuk meneliti hubungan antara GJH dengan keseimbangan statis pada penari di Kota Denpasar.

\section{METODE}

Penelitian ini menggunakan rancangan penelitian analitik dengan pendekatan cross sectional. Sampel dianalisis berdasarkan skor beighton yaitu kelompok GJH $(\geq 4)$ dan non-GJH (<4). Pengukuran keseimbangan menggunakan standing stork test.

Penelitian ini dilakukan di beberapa tempat antara lain: hypehope dance studio, NG dance studio, universal dance studio, neutral dance studio, dan corallight dance studio. Penelitian dilakukan pada bulan April hingga Mei 2019. Kriteria intrinsik sampel pada penelitian ini ialah: 1) Penari modern yang berdomisili di Denpasar; 2) Berjenis kelamin perempuan; 3) Berusia 16 - 25 tahun; dan 4) Memiliki pengalaman menari > 1 tahun. Kriteria ekstrinsik ialah: 1) Subjek pasca operasi fraktur atau cedera muskoloskeletal lainnya pada ekstremitas atas atau bawah; 2) Subjek dengan joint hypermobility syndrome (JHS); 3) Subjek dengan cedera akut pada ekstremitas atas atau bawah; 4) Subjek dengan tanda-tanda inflamasi akut pada persendian; 5) Subjek dengan nyeri pada persendian dalam 1 bulan terakhir; 6) Subjek yang obesitas atau IMT > 29,9.

\section{HASIL}

Karakteristik sampel berdasarkan usia, IMT, beighton score, dan keseimbangan statis adalah sebagai berikut:

Tabel 1. Karakteristik Sampel

\begin{tabular}{lcc}
\hline \multicolumn{1}{c}{ Karakteristik } & $\begin{array}{c}\text { Frekuensi } \\
\text { (n) }\end{array}$ & $\begin{array}{c}\text { Persentase } \\
\text { (\%) }\end{array}$ \\
\hline Usia & & \\
\hline 16-20 Tahun & 37 & 77,1 \\
21-25 Tahun & 11 & 22,9 \\
\hline IMT & & \\
\hline Underweight & 1 & 2,1 \\
Normal & 40 & 83,3 \\
Overweight & 7 & 14,6 \\
\hline Beighton Score & & \\
\hline GJH $(\geq 4)$ & 30 & 62,5
\end{tabular}




\begin{tabular}{lcc} 
Non-GJH $(<4)$ & 18 & 37,5 \\
\hline Keseimbangan Statis & & \\
\hline Buruk & 22 & 45,8 \\
Dibawah Rata-Rata & 12 & 25 \\
Diatas Rata-Rata & 9 & 18,8 \\
Baik & 3 & 6,3 \\
Sangat Baik & 2 & 4,2 \\
\hline
\end{tabular}

Tabel 1 menunjukkan karakteristik sampel penelitian berdasarkan usia, IMT, beighton score, dan keseimbangan statis. Karakteristik sampel berdasarkan usia terbanyak ialah pada usia 16-20 tahun yaitu sejumlah 37 orang $(77,1 \%)$ dan pada usia 21-25 tahun sejumlah 11 orang (22,9\%). Karakteristik sampel berdasarkan IMT dari 48 orang memiliki IMT underweight sejumlah 1 orang (2,1\%), sampel yang mempunyai IMT normal sejumlah 40 orang $(83,3 \%)$, dan sampel yang mempunyai IMT overweight sejumlah 7 orang (14,6\%). Karakteristik sampel berdasarkan beighton score didapatkan sejumlah 30 orang $(62,5 \%)$ yang mempunyai skor $\geq 4$ dan termasuk kategori generalized joint hypermobility (GJH) sedangkan sejumlah 18 orang $(37,5 \%)$ termasuk kategori non-GJH. Karakteristik sampel berdasarkan keseimbangan statis sejumlah 22 orang $(45,8 \%)$ yang mempunyai keseimbangan statis buruk, 12 orang $(25,0 \%)$ yang memiliki keseimbangan statis dibawah rata-rata, 9 orang $(18,8 \%)$ yang memiliki keseimbangan statis baik, 3 orang $(6,3 \%)$ dan 2 orang $(4,2 \%)$ yang memiliki keseimbangan statis sangat baik.

Tabel 2. Uji Normalitas One-Sample Kolmogorov-Smirnov Test

\begin{tabular}{cc}
\hline Variabel & Nilai $\mathbf{p}$ \\
\hline Generalized joint hypermobility (GJH) & 0,046 \\
Keseimbangan statis & 0,000 \\
\hline
\end{tabular}

Berdasarkan Tabel 2, data GJH memiliki nilai $p=0,046$ dan keseimbangan statis memiliki $p=0,000$. Keseluruhan data memiliki nilai $p<0,05$ dan menunjukkan seluruh data variabel berdistribusi tidak normal. Sehingga uji hipotesis yang digunakan adalah non parametrik.

Tabel 3. Crosstabulation Hubungan Generalized Joint Hypermobility (GJH) dengan Keseimbangan Statis

\begin{tabular}{lcccc}
\hline Keseimbangan Statis & \multicolumn{2}{c}{ GJH } & Jumlah & $\mathbf{p}$ \\
\cline { 2 - 3 } & Ya & Tidak & & \\
\hline Buruk & 22 & 0 & 22 & 0,000 \\
Dibawah Rata-rata & 6 & 6 & 12 & \\
Diatas Rata-rata & 2 & 7 & 9 & \\
Baik & 0 & 3 & 3 & \\
Sangat Baik & 0 & 2 & 2 & \\
\hline Jumlah & 30 & 18 & 48 & \\
\hline
\end{tabular}

Tabel 3 menunjukkan hasil crosstabulation hubungan generalized joint hypermobility (GJH) dengan keseimbangan statis pada penari modern perempuan di Kota Denpasar. Data menunjukkan bahwa pada sampel generalized joint hypermobility (GJH) lebih banyak memiliki keseimbangan statis buruk, dan sampel non-GJH memiliki keseimbangan statis lebih baik.

Tabel 4. Hubungan Generalized Joint Hypermobility (GJH) dengan Keseimbangan Statis dengan Uji Spearman's Rho

\begin{tabular}{ccc}
\hline Variabel & \multicolumn{1}{c}{ Keseimbangan Statis } \\
\hline Generalized Joint Hypermobility (GJH) & $r$ & $p$ \\
& $-0,688$ & 0,000 \\
\hline
\end{tabular}

Berdasarkan data pada Tabel 4 diperoleh nilai $p=0,000(p<0,05)$ yang menunjukkan adanya hubungan yang signifikan antara generalized joint hypermobility $(\mathrm{GJH})$ dengan keseimbangan statis. Nilai $r=-0,688$ menunjukkan bahwa GJH berhubungan secara negatif (berlawanan arah) dengan keseimbangan statis. Uji signifikan koefisien korelasi dengan perhitungan $\mathrm{Kp}$ diperoleh hasil $47,33 \%$ dan didapatkan bahwa keseimbangan statis dipengaruhi oleh generalized joint hypermobility (GJH) sebesar 47,33\%.

\section{DISKUSI}

Penelitian dilakukan selama bulan April hingga Mei 2019. Pada penelitian ini dari keseluruhan total 15 tim tari modern, terpilih 6 tim dengan teknik cluster random sampling. Dari 6 tim tari, diperoleh sampel sejumlah 48 orang perempuan berdasarkan kriteria inklusi dan eksklusi penelitian. Sampel yang termasuk dalam penelitian ini adalah usia 16-25 tahun. Berdasarkan hasil data sampel, didapat rerata usia sampel pada penelitian ini yaitu sebesar 19,08 dengan usia terkecil 16 tahun dan tertinggi 25 tahun. Kondisi generalized joint hypermobility (GJH) dipengaruhi oleh faktor usia. Penelitian yang dilakukan oleh Schmidt et al. menemukan prevalensi GJH berkisar antara $2-57 \%$ dan tergantung pada usia, jenis kelamin dan ras. Prevalensi GJH lebih tinggi ditemukan pada usia anak-anak hingga dewasa muda. Sejalan dengan penelitian yang dilakukan oleh Scheper et al. yang menyatakan penari elit usia remaja hingga dewasa muda dengan kisaran usia 17 - 20 tahun memiliki prevalensi GJH yang lebih tinggi dibandingkan kelompok usia lainnya ${ }^{9}$. Kelenturan sendi akan berkurang seiring bertambahnya usia, hal ini akan menyebabkan kondisi generalized joint hypermobility (GJH) lebih jarang ditemukan pada orang dewasa.

Berdasarkan hasil penelitian diperoleh data sampel dengan GJH sebanyak 62,5\% dan non GJH sebanyak 37,5\%. Sejalan dengan penelitian yang dilakukan oleh Ruemper yang menemukan bahwa tingkat GJH pada penari kontemporer sebesar $69 \%{ }^{15}$. Penelitian ini juga sejalan dengan penelitian oleh Sanches yang meneliti prevalensi GJH 
pada pelatih dan penari balet di Brazil. Sanches menemukan hasil 58\% total sampel memiliki GJH ${ }^{16}$. Populasi yang berisiko tinggi terhadap GJH adalah penari. Gerakan yang repetitif dan kompleks pada tarian menyebabkan meningkatnya lingkup gerak sendi ${ }^{17}$. GJH memberikan dampak positif dalam segi estetika tarian, namun dapat menjadi dampak buruk bagi kondisi muskuloskeletal penari. Individu dengan GJH mengalami penurunan kebugaran fisik (kekuatan otot dan stamina) yang menyebabkan terjadinya kelelahan dini, terganggunya fungsi proprioseptif, serta tingginya tingkat depresi dan kecemasan. Pada penari, tingkat insiden cedera musculoskeletal lebih tinggi pada ekstremitas bawah dan tulang belakang disebabkan karena kerusakan jaringan lunak dan cedera overuse ${ }^{9}$.

Data hasil pengukuran keseimbangan statis dengan standing stork test menunjukkan bahwa 45,8\% sampel termasuk dalam kategori keseimbangan buruk. Tekin dalam penelitiannya menyatakan bahwa latihan tari modern saja tidak dapat meningkatkan keseimbangan pada penari dibandingkan dengan kinesio taping dan proprioceptive neuromuscular training ${ }^{18}$. Sejalan dengan penelitian oleh Marulli yang menyatakan bahwa penari modern memiliki tingkat keseimbangan yang lebih buruk dibandingkan dengan penari balet. Hal ini dikarenakan jenis gerakan pointé pada tari balet menstimulasi penari untuk mempertahankan keseimbangan dengan satu kaki ${ }^{17}$. Pada tari modern gerakan sangat bebas dan tidak terfokus pada satu ekstremitas saja, oleh karena itu keseimbangan pada penari modern lebih buruk dibandingkan penari balet.

Korelasi antara GJH dengan keseimbangan statis dengan menggunakan uji statistik spearman's rho menunjukkan hasil sebesar $r=-0,688$ dengan nilai $p=0,000$. Nilai $p<0,05$ menunjukkan bahwa terdapat hubungan yang signifikan antara GJH dengan keseimbangan statis pada penari di Kota Denpasar. Tanda negatif memiliki makna bahwa kedua variabel memiliki hubungan yang berlawanan arah. Hubungan berlawanan arah memberikan arti bahwa semakin tinggi nilai beighton score yang menyatakan kondisi GJH pada seorang individu, maka semakin rendah tingkat keseimbangan statis individu tersebut.

Keseimbangan statis pada sampel GJH yang berjumlah 30 orang terdapat 22 orang dengan keseimbangan statis buruk, 6 orang dengan keseimbangan statis dibawah rata-rata dan 2 orang dengan keseimbangan statis diatas ratarata. Sampel non - GJH dengan total 18 orang terdapat 6 orang dengan keseimbangan statis dibawah rata-rata, 7 orang dengan keseimbangan statis diatas rata-rata, 3 orang dengan keseimbangan statis baik dan 2 orang dengan keseimbangan statis sangat baik. Data tersebut menunjukkan bahwa sebagian besar sampel dengan GJH termasuk dalam keseimbangan statis kategori buruk dan dibawah rata-rata. Pada sampel non-GJH ditemukan kategori keseimbangan statis yang lebih baik. Sebagian besar sampel non-GJH termasuk dalam keseimbangan statis kategori diatas rata-rata hingga sangat baik.

Penelitian yang dilakukan oleh latridou, meneliti tentang hubungan keseimbangan statis dan dinamis pada perempuan dengan GJH. Keseimbangan statis diukur dengan one-leg stance EO-HE (eyes open-head extention). Informasi sensoris untuk mempertahankan keseimbangan didapat dari proprioseptif yang terdapat pada stabilisator pasif (seperti ligament dan kapsul) dan stabilisator aktif (otot). Gangguan penyampaian informasi aferen, akan menyebabkan terganggunya fungsi eferen untuk mengaktifkan otot sehingga menimbulkan kondisi tidak seimbang atau goyangan postural (postural sway) ${ }^{19}$. Hasil penelitian tersebut sejalan dengan penelitian ini, yaitu bahwa perempuan dengan GJH memiliki kondisi yang tidak seimbang atau goyangan postural (postural sway) saat mempertahankan keseimbangan statis dibandingkan dengan non-GJH.

Juul-Kristensen melakukan penelitian terhadap perubahan aktivitas otot dan goyangan postural (postural sway) pada perempuan dengan GJH selama mempertahankan keseimbangan statis ${ }^{20}$. Sampel yang digunakan adalah usia 14 tahun dan dikategorikan ke dalam 2 kelompok, yaitu GJH (16 orang) dan non-GJH (11 orang). Juul-Kristensen melakukan pengukuran keseimbangan statis dengan 3 cara yaitu berdiri pada kedua kaki dengan mata terbuka, berdiri pada kedua kaki dengan mata tertutup, dan berdiri pada satu kaki dengan mata terbuka. Penelitian tersebut menunjukkan bahwa terdapat ketidakseimbangan kerja otot pada individu dengan GJH (minimal salah satu lutut hypermobile) dan menyebabkan terjadinya kondisi yang tidak seimbang atau goyangan postural (postural sway). Postural sway lebih banyak ditemukan saat kondisi mata tertutup. Keseimbangan kerja otot antara otot agonis dan antagonis, dan antara sisi medial dan lateral otot sangatlah penting dalam fungsi normal lutut. Ketidakseimbangan kerja otot akan berpengaruh pada mekanisme tubuh mempertahankan keseimbangan ${ }^{20}$.

Hasil penelitian ini didukung oleh Rombaut, yang menyatakan bahwa kondisi GJH akan menyebabkan penurunan tingkat keseimbangan individu. Berdasarkan penelitian tersebut, ditemukan bahwa individu dengan GJH mengalami postural sway kearah anterior-posterior (AP) dan medial-lateral (ML) saat melakukan pemeriksaan keseimbangan statis. Grup GJH memiliki simpang baku AP sway dan ML sway 2-7 kali lebih besar dibandingkan dengan kontrol grup ${ }^{21}$.

Marulli menyatakan bahwa tidak terdapat hubungan antara GJH dengan keseimbangan statis pada penari ${ }^{17}$. Sampel pada penelitian Marulli adalah penari modern, penari balet professional dan penari balet pre-profesional. Pengukuran keseimbangan statis dilakukan dengan cara berdiri pada satu kaki dengan menutup mata. Hasil penelitian menunjukkan $p=0,154$ yang memiliki arti bahwa tidak terdapat hubungan antara GJH dan keseimbangan statis pada penari. Namun, Marulli menyatakan faktor bias yang menyebabkan hal ini adalah perbedaan jenis tarian dari para penari. Penari modern dengan penari balet memiliki rutinitas latihan yang berbeda, gerakan dan usur-unsur tarian pun juga berbeda. Hal ini dapat mempengaruhi tingkat keseimbangan statis pada penari. Oleh karena ini, pada penelitian ini penari yang termasuk kriteria inklusi hanyalah penari modern.

Hasil perhitungan kekuatan hubungan (Kp) antara GJH dengan keseimbangan statis adalah 47,33\%. Hasil tersebut menunjukkan bahwa keseimbangan statis dipengaruhi oleh GJH sebesar 47,33\%, sedangkan 52,67\% dipengaruhi oleh faktor lainnya seperti usia, jenis kelamin, aktivitas fisik, dan faktor lingkungan ${ }^{22}$.

Keseimbangan dipengaruhi oleh faktor internal dan faktor eksternal. Faktor internal yang dapat mempengaruhi keseimbangan adalah sistem informasi sensoris yaitu meliputi visual, vestibular dan somatosensoris. Individu dengan GJH mengalami penurunan fungsi somatosensoris terutama proprioseptif. Hal ini didukung oleh Czaprowski \& Sitarski yang menyatakan bahwa kondisi sendi yang hypermobile akan menyebabkan terganggunya fungsi proprioseptif 
sehingga individu kesulitan untuk mengetahui posisi sendi dan dapat berujung pada cedera sendi berulang dan instabilitas sendi? Selain informasi sensoris, keseimbangan juga dipengaruhi oleh kerja eferen yaitu sistem motorik. GJH akan mengakibatkan gangguan pada sistem muskuloskeletal. Hal ini didukung oleh Rombaut yang menyatakan bahwa pada individu GJH ditemukan kelemahan pada otot ekstremitas bawah, terutama otot quadriceps dan dapat mengakibatkan instabilitas postur ${ }^{21}$. Keseimbangan statis dipengaruhi pula oleh faktor eksternal yaitu faktor lingkungan. Pada penelitian ini, faktor lingkungan tidak termasuk dalam variabel yang dikontrol. Lingkungan tempat penelitian di satu kelompok tari dengan kelompok tari lainnya sangatlah berbeda. Kondisi permukaan lantai dan tingkat kebisingan lingkungan penelitian diduga dapat menjadi faktor bias pada penelitian ini.

\section{SIMPULAN}

Berdasarkan hasil penelitian yang telah dilakukan maka dapat disimpulkan bahwa terdapat hubungan antara GJH dengan keseimbangan statis pada penari di Kota Denpasar.

\section{DAFTAR PUSTAKA}

1. Permana, DFW. 2013. Perkembangan Keseimbangan pada Anak Usia 7 s/d 12 Tahun Ditinjau dari Jenis Kelamin. Jurnal Media IImu Keolahragaan Indonesia, 3(1): 25-29

2. Kusumaningrum, PW. 2016. Hubungan Latihan Gerak Dasar Tari Tradisional Gaya Surakarta dengan Keseimbangan Dinamis pada Remaja Putri Usia 14 - 16 Tahun [Skripsi]. Jawa Tengah : Universitas Muhammadyah Surakarta.

3. Elpidoforou, M. 2016. Overuse Injuries in Dancers. West Attica. OMIC Group eBook: pp1-9. Available at: https://books.google.co.id

4. Gamboa JM, Roberts LA, Maring J, Fergus A. 2008. Injury Patterns in Elite Preprofessional Ballet Dancers and The Utility of Screening Programs to Identify Risk Characteristics. Journal of Orthopaedic \& Sports Physical Therapy, 38(3): 126-136.

5. Hincapié CA, Morton EJ, Cassidy JD. 2008. Musculoskeletal Injuries and Pain in Dancers: a systematic review. Archives of Physical Medicine and Rehabilitation, 89(9): 19-29.

6. Stracciolini A, Yin AX, Sugimoto D. 2015. Etiology and Body Area of Injuries in Young Female Dancers. The Physician and Sport Medicine, 43(4): 342-347.

7. Czaprowski, D, Sitarski, D. 2016. Generalized Joint Hypermobility, Diagnosis and Physiotherapy. Journal of Novel Physiotherapies, 6(4).

8. Kwon JW, Lee WJ, Park SB, Kim MJ, Jang SH, Choi CK. 2013. Generalized Joint Hypermobility in Healthy Female Korean: Prevalence and Age-Related Differences. Annals of Rehabilitation Medicine 37(6): 832-838.

9. Scheper, MC De Vries JE, De Yos R, Verbunt J, Nollet F, \& Engelbert R. 2013. Generalized Joint Hypermobility in Professional Dancers. Rheumatology (United Kingdom), 52(4): 651-658.

10. Chan C, Hopper L, Zhang F, Pacey V, Nicholson LL. 2018. The Prevalence of Generalized Joint Hypermobility in Elite Australian Dancers. Physical Therapy in Sport, 32(3): 15-21

11. Castori M, Colombi M. 2015. Generalized Joint Hypermobility, Joint Hypermobility Syndrome and Ehler-Danlos Syndrome, Hypermobility Type. American Journal of Medical Genetics, 169(1): 25-34.

12. Engelbert RH, Bank RA, Sakkers RJ, Helders PJ, Beemer FA, Uiterwaal CS. 2003. Pediatric Generalized Joint Hypermobility With and Without Muculoskeletal Complaints. Pediatrics, 111(3): 248-254.

13. Scheper M, Vries, J, Beelen A, Vos R, Nollet F, \& Engelbert R. 2015. Generalized Joint Hypermobility, Muscle Strength and Physical Function in Healthy Adolescents and Young Adults. Current Rheumatology Reviews, 10(2): 117-125.

14. Yasemin U, Yesim A, Berna T, Dilek D, Ayhan B, Omer K. 2013. Is There a Balance Problem in Hypermobile Patients with Fibromyalgia. Turkish Journal of Reumatology, 28(1): 10-15.

15. Ruemper A, Watkins K. 2012. Correlations Between Generalized Joint Hypermobility and Joint Hypermobilty Syndrome and Injury in Contemporary Dance. Journal of Dance Medicine \& Science, 16(4): 161-166.

16. Sanches SB, Oliviera GM, Osorio FL, Crippa JA, Martin SR. 2015. Hypermobilty and Joint Hypermobility Syndrome in Brazilian Students and Teachers of Ballet Dance. Rheumatology International, 35(4): 741-747.

17. Marulli TA, Matthews LE, Coen JH, Willigenburg NW, Hewett TE. 2017. Eyes-Closed Single-Limb Balance is Not Related to Hypermobility Status in Dancers. Journal of Dance Medicine \& Science, 21(2): 70-75.

18. Tekin D, Agopyan A, Baltaci G. 2018. Balance Training in Modern Dancers: Proprioceptive-Neuromuscular Training vs Kinesio Taping. Medical Problems of Performing Artists, 33(3): 156-165.

19. Iatridou K, Mandalidis D, Chronopoulos E, Athanasopoulos S, Vagenas G. 2014. Static and Dynamic Body Balance Following Provocation of The Visual and Vestibular System in Females With and Without Hypermobility Syndrome. Journal of Bodywork and Movement Therapies, 18(2): 159-164.

20. Juul-Kristensen B, Johansen KI, Hendriksen P, Melcher P, Sandfeld J, Jensen BR. 2016. Girls With Generalized Joint Hypermobility Display Changed Muscle Activity and Postural Sway During Static Balance Tasks. Scandinavian Journal of Rheumatology, 45(1): 57-65.

21. Rombaut L, Malfait F, Wandele ID, Thijs Y, Palmans T, De-Paepe A, Calders P. 2011. Balance, Gait, Falls, and Fear of Falling in Women With The Hypermobility Type of Ehler-Danlos Syndrome. Arthritis Care and Research, 63(10): 1432-1439.

22. Antara KA, Adiputra IN, \& Sugiritama IW. 2017. Hubungan Flat Foot Dengan Keseimbangan Statis dan Dinamis pada Anak Sekolah Dasar Negeri 4 Tonja Kota Denpasar. Majalah IImiah Fisioterapi Indonesia, 5(3): 25-30 